\title{
Drive systems of the drilling rigs for open pits in Ukraine: state and ways for improvement
}

\author{
Viktor Khilov ${ }^{1 *}$, Nataliia Hlukhova ${ }^{1}$, Andrii Somin ${ }^{1}$, and Volodymyr Kiiko ${ }^{1}$ \\ ${ }^{1}$ Dnipro University of Technology, Electro-Technical Department, 19 Yavornytskoho, 49005 Dnipro, \\ Ukraine
}

\begin{abstract}
A comparative analysis is presented of the characteristics of drilling rigs used in open-pit mining in Ukraine. The experimental studies have been conducted of the drive systems and drilling rigs influence on the dynamics of the drilling process under the mining and geological conditions of the Central Mining and Processing Plant (Kryvyi Rih city, Ukraine). The frequency characteristics have been obtained and the dynamic properties of the automated drive systems, as well as frequency characteristics of the rotation mechanism transmissions have been analyzed. The behavior of natural oscillation frequencies in closed control loops of rotational drives was studied, and it has been determined that they exceed the cutoff frequency and fall into the pass band from the attenuation band in frequency-controlled induction motors of most advanced drilling rigs with the maximum number of rods connected in the drill string. It has been established that low oscillation frequencies due to the side frequencies, generated by the drill rod oscillations, fall into the fastest internal current loop. The tasks have been formulated for further research. The purpose of research is to solve the actual scientific and applied problem of dynamic compatibility of frequency characteristics in the modern high speed drive systems with the dynamic characteristics of drilling rigs, which are multi-mass mechanisms with distributed and concentrated parameters with a change in added masses.
\end{abstract}

\section{Introduction}

When conducting open-pit mining, the drilling of blast-holes is one of the main very laborintensive and expensive operations $[1-6]$. The main problems of the open-pit method of mining include physical and moral aging of drilling equipment [3, 4]. Therefore, the modernization of equipment and the creation of a new generation of drilling rigs are important scientific and technical problems, on the solution of which depends the successful functioning of Ukraine mining industry.

The acquisition of drilling equipment in the near-abroad countries [7-9] requires significant investments and will not provide an increase in the technical and economic indicators of mining, machine-building and electro-technical industry of the near-abroad countries, because during the last fifteen - seventeen years they have gone through a

\footnotetext{
*Corresponding author: khiloff@gmail.com
} 
difficult period in their existence, which adversely affected the development and release of new equipment.

The Ukrainian machine-building plants produced the USBSh-250A drilling rigs (they have been working at the Poltava Mining and Processing Plant since 2004) - an analogue of the SBSh-250/270-32 machine and principally new machines developed by Novokramatorsky Mashinostroitelny Zavod PJSC (LLC NKMZ) (implemented at Ingulets Iron Ore Mining and Processing Works PrAT in 1999), as well as SBShS-250N (works at the Central Mining and Processing Plant since 2003) [5 - 7].

Comparative characteristics of existing drilling rigs are given in Table 1, from which it follows that the technical parameters of the new-generation drilling rigs, developed by Ukrainian machine builders, correspond to the medium type, and according to the power equipment - to heavy one. This determines their improved efficiency.

Along with the improvement of the mechanical part of drilling rigs, it is necessary to modernize the drive system, which should correspond to the achieved level in the global electrical engineering industry $[8-16]$. Only in this case it is possible to create a competitive mining machine as a whole.

Since 1997, teams of employees of the Institute of Electrical Power Engineering of the National Mining University and LLC ORKIS have been conducting scientific and technical developments aimed at designing energy- and resource-saving drive systems for mining machines, both of the new generation and for those operating at the Mining and Processing Plants of Ukraine [17].

As part of the work carried out in the process of upgrading the equipment, the following unique AC drive systems for SBSh-250MN-32 drilling rigs have been introduced, which are operated at the Central Mining and Processing Plant: an thyristor AC drive with a power source on the reconstructed drilling rig (operation period from 1998 to 2006), transistor AC drives with a power source on modernized drilling rigs (operation period from 2005), transistor power converters with a power source (firm "Triol Corporation") on a unique SBShS-250N drilling rig (from 2003) [18 - 23].

In foreign countries, electro-hydraulic or diesel-hydraulic drive systems, as a rule, are used in drilling rigs. Foreign rotary drilling rigs are manufactured by Atlas Copco, Ingersoll-Rand, Bucyrus-Erie, Tamrock-Driltech, Harnischfeger P\&X and others. They have created rotary drilling rigs, which allow the use not only rolling, but cutting bits, as well as pneumatic impact tools. Constructive solutions, specific for rigs manufactured by foreign companies have a steady tendency to use hydraulics in the main drives. These include the hydraulics of the drives of all rig systems, based on the use of a single primary diesel engine that drives the compressor and pumping station. The latter feeds the main hydraulic drives of the rig [24-29].

The drilling rigs of Atlas Copco, Tamrock, Reedrill and other Western companies are more productive than SBSh-250MN-32 due to the use of a diesel drive, which makes them independent of the power cutoff at the quarry and gives a gain when moving the rig from one drilling block to another. At the same time, the cost of energy for diesel engines exceeds the cost of energy for drilling machines SBSh-250MN-32 almost by 6 times.

In neighboring countries, the UGMK Rudgormash Company (RF) first introduced in 2008 in Khakasiia an integrated frequency electric drive using the ATV 71 frequency converter manufactured by Schneider Electric (France).

Comparative characteristics of drilling rigs operating in open-pit mining operations of Ukraine is given in Table 1. 
Table 1. Comparative characteristics of drilling rigs used in open-pit mining of Ukraine.

\begin{tabular}{|l|c|c|c|c|c|c|}
\hline \multirow{2}{*}{$\begin{array}{c}\text { Drilling machine } \\
\text { types }\end{array}$} & \multicolumn{7}{|c|}{ Technical characteristics of drilling machines } \\
\cline { 2 - 7 } & $\begin{array}{c}2 \text { SBSh- } \\
200 \mathrm{~N}\end{array}$ & $\begin{array}{c}\text { SBSh- } \\
250 \mathrm{MN}-32\end{array}$ & SBSh-320 & $\begin{array}{c}\text { SBSh- } \\
250 / 270-32\end{array}$ & $\begin{array}{c}\text { SBShS- } \\
250 \mathrm{~N}\end{array}$ & $\begin{array}{c}\text { USBSh- } \\
250 \mathrm{~A}\end{array}$ \\
\hline Manufacturer & Russia & Russia & Russia & Ukraine & Ukraine & Ukraine \\
\hline Bit diameter, mm & $214 ; 244$ & $244 ; 269$ & 320 & 250 & 250 & 250 \\
\hline $\begin{array}{l}\text { Depth of drilling, } \\
\mathrm{m}\end{array}$ & 40 & 34 & 40 & 32 & 44 & 32 \\
\hline Axial load, kN & 245 & 294 & 588 & 300 & 350 & 300 \\
\hline $\begin{array}{l}\text { Angular bit speed, } \\
\text { rad/s }\end{array}$ & $0-33$ & $0-16$ & $0-13.6$ & $0-12$ & $0-12$ & $0-13$ \\
\hline Feed rate, mm/s & 21.7 & 15.0 & 16.7 & 15.0 & 16.0 & 15.0 \\
\hline $\begin{array}{l}\text { Engine efficiency } \\
\text { of the drill string } \\
\text { rotation, } \mathrm{kW}\end{array}$ & 50.0 & 50.75 & 100.0 & 90.0 & 90.0 & 90.0 \\
\hline $\begin{array}{l}\text { Compressor } \\
\text { capacity, } \mathrm{m}^{3} / \mathrm{s}\end{array}$ & 0.416 & 0.416 & 0.833 & 0.416 & 0.533 & 0.416 \\
\hline $\begin{array}{l}\text { Total engine } \\
\text { efficiency, } \mathrm{kW}\end{array}$ & 282 & 386 & 712 & 420 & 545 & 390 \\
\hline Machine weight, t & 50 & 65 & 110 & 68 & 79 & 69 \\
\hline
\end{tabular}

\section{Experimental studies of types influence of drive systems and drilling rigs on the drilling process dynamics}

To assess the degree of types influence of drive systems and drilling rigs on the level of vibration arising during drilling, experimental studies were conducted in the mining and geological conditions of the Central Mining and Processing Plant. The following factors were fixed during the test: hardness factor, drilling category, rock fracturing, water content in the well and, if possible, other factors affecting the process of the drilling rig vibrations. The drilling on all drilling rigs was carried out with the same axial pressure on the rolling bit and with the same rotation frequency. During the study, the 243-OKP rolling bits were used identical in design. Physical and mechanical properties of rocks for each test had been fixed.

The vibration sensor has been set at the intersection of the drill head pressure in the immediate vicinity of the drilling supporting node, and the power and current sensors of the rotation actuator were inside the engine room of the drilling rig in the power supply block of the semiconductor converter.

Oscillograms of transition curves of anchor current, rotation frequency, vibration shift and power consumption of the DC thyristor drive of the assembly of the SBSh-250MN-32 drilling machine under operational conditions at the Central Mining and Processing Plant, when starting from the power-up sensor and beginning of drilling on non-oxidized magnetite ore (hardness factor by the M.M. Protodiakonov's scale $f=16-17$; V category of drilling; medium-fractured rocks) are shown in Fig. 1a.

The harmonic analysis of the vibration shift curve (Fig. 2a, b) has shown that with an increase in the rotation frequency of the drill rod, the amplitude-frequency characteristics shift in proportion in the direction of high frequencies. The latter circumstance indicates that the drill rod vibrations are caused by forced vibrations due to the interaction of the drilling tool with the rock in the zone of destruction.

Oscillograms of changes in the stator current, rotational speed, power consumption of an induction motor from a controlled thyristor current source [7], at the start-up and beginning of drilling by using an $\mathrm{AC}$ drive system on unoxidized hematite-magnetite ore with rock hardness according to M.M. Protodyakonov's scale $f=17-20$, VI category of 
drilling, pressure on the drilling machine assembly $250 \mathrm{kN}$ in the conditions of the Central Mining and Processing Plant, are shown in Fig. 1b. The drive rotation system with an induction motor and a controlled thyristor current source is protected by a patent of Ukraine [28].

$a$

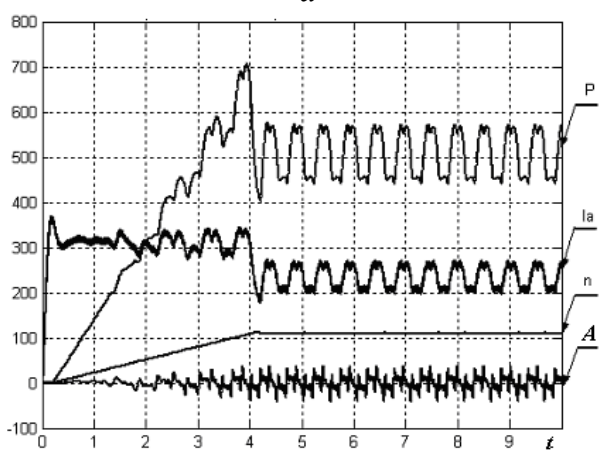

$b$

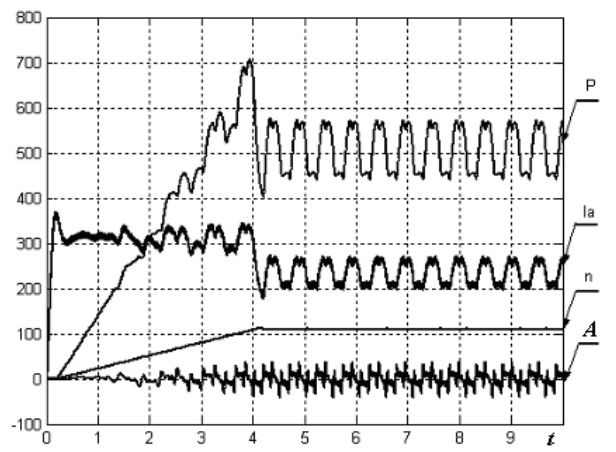

Fig. 1. Oscillograms of transients in a thyristor drive (a - DC; b - AC) of the SBSh-250MN-32 drilling rig at the start-up and beginning of drilling: $P$ - power consumption, $\mathrm{kW} ; I a$ - anchor current, A; $n$-rotation frequency, rpm; $A$ - vibration shift, $\mu \mathrm{m} ; t$ - current time, $\mathrm{s}$.

The width of the pass band of rotation frequency loop in the thyristor AC drive is up to $50 \mathrm{rad} / \mathrm{s}$. Due to the lower inertia of the induction motor rotor, compared to DC motors in an AC drive, the amplitudes of oscillations of the rotational speed of the motor shaft are increased when the resistance moment is changed on the rolling bit. The ripple of the motor current is $25.3 \%$, the ripple of the rotation frequency of the motor shaft is $2.56 \%$.

The frequency analysis of the vibration shift curve when drilling by the drive system according to the scheme of the regulated current source - an induction motor (Fig. 2c, d) indicates that the pattern which occurs during drilling using a thyristor DC drive is also fulfilled when using a thyristor AC drive.

The use of a transistor frequency-controlled drive on the SBSh-250MN-32 machine [7] leads to the amplification of high-frequency components in the vibration curve. Oscillograms of transient processes are shown in Fig. 3a (drilling on oxidized martitehematite ores: the hardness factor according to the M.M. Protodyakonov's scale is $13-15$; the drilling category according to the Central Mining Plant scale is IV, very fractured, the distance between the fractures is $0.2-0.3 \mathrm{~m}$; axial pressure $240 \mathrm{kN}$ ), from which it follows that the expansion of the pass band of rotation frequency loop to $200 \mathrm{rad} / \mathrm{s}$ and a decrease in the rotor inertia moment leads to an increase in the amplitude of the rotational frequency oscillations as compared to thyristor DC drives and AC drives. The ripples of the motor current make up $25.6 \%$, the ripples of the rotation frequency of the motor shaft $-3.51 \%$.

Based on the amplitude-frequency characteristics of the oscillations displacement, which are shown in Fig. 4a, b, it turns out that when using the same type of drilling rig (SBSh-250MN-32), the pattern that occurred during drilling with thyristor drive systems is preserved even when changing to transistor drive systems - the vibrations are caused also by forced oscillations of the drilling rig assembly. The difference is in the values of the oscillation amplitudes. 
$b$

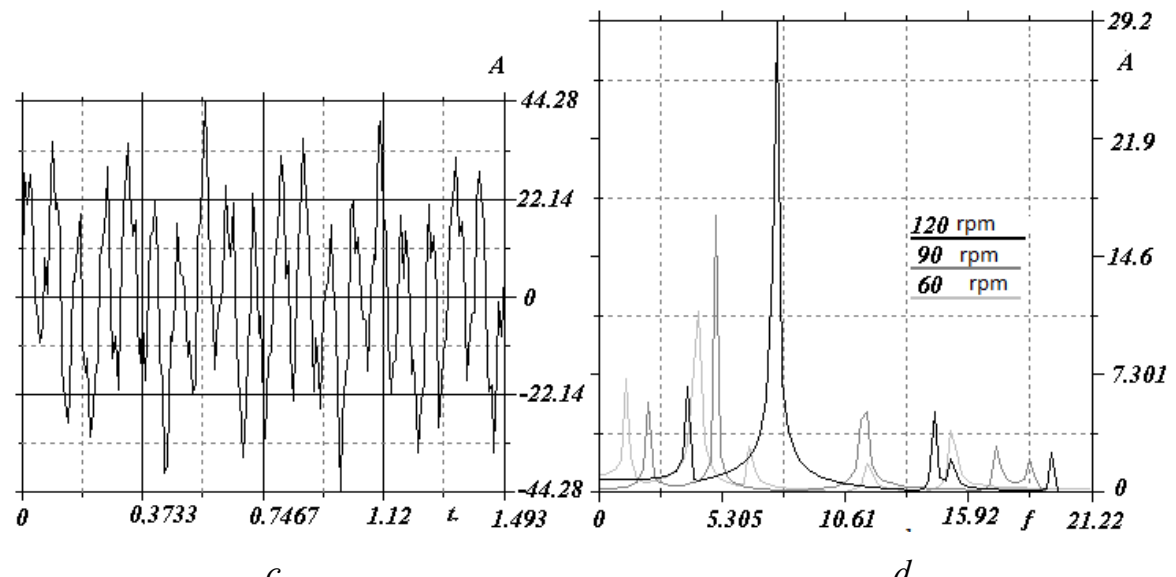

$c$

$d$

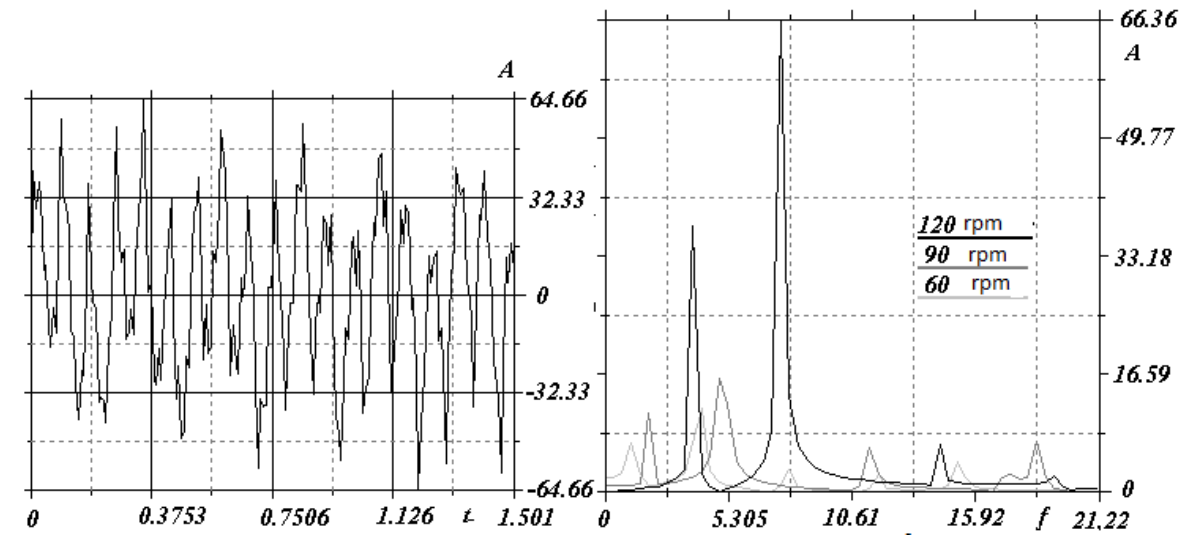

Fig. 2. Oscillogram of vibration shift of the pressure cross-arm of the drill head at a frequency of $60 \mathrm{rpm}$ (a, c) and spectra of the amplitude-frequency characteristics of oscillations (b, d) of the SBSh-250MN32 drilling rig with a thyristor drive $(\mathrm{a}, \mathrm{b}-\mathrm{DC} ; \mathrm{c}, \mathrm{d}-\mathrm{AC})$ when axial pressure $250 \mathrm{kN}$, drilling with two drill rods: $A$ - vibration shift, $\mu \mathrm{m} ; t$ - current time, $\mathrm{s} ; f$ - frequency of oscillations, $\mathrm{Hz}$.

$a$

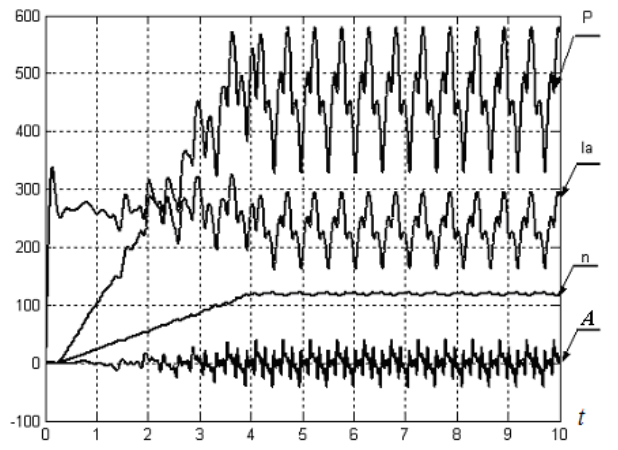

$b$

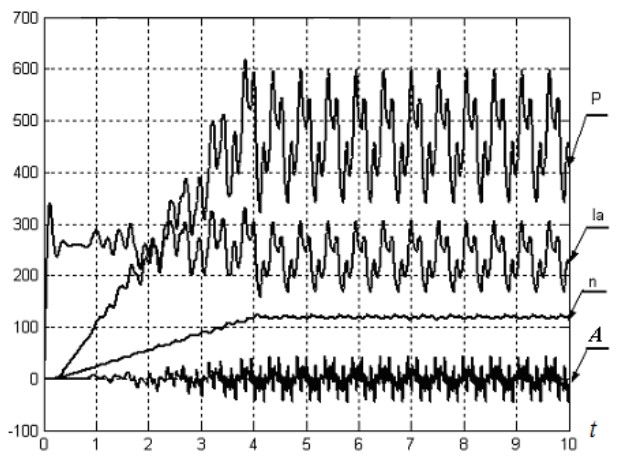

Fig. 3. Oscillograms of transients in transistor AC drive (drilling rig: a - SBSh-250MN-32; b SBShS-250N) at the start-up and beginning of drilling: $P$ - power consumption, $\mathrm{kW} ; I a-$ stator current, $\mathrm{A} ; n$ - rotation frequency, rpm; $A$ - vibration shift, $\mu \mathrm{m} ; t$ - current time, $\mathrm{s}$. 
$a$

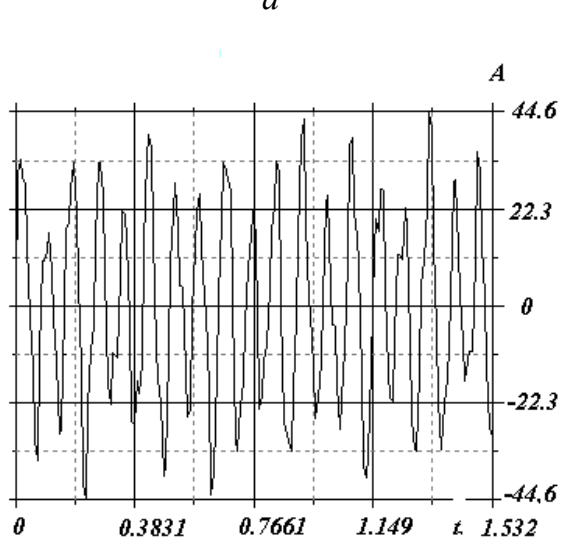

$c$

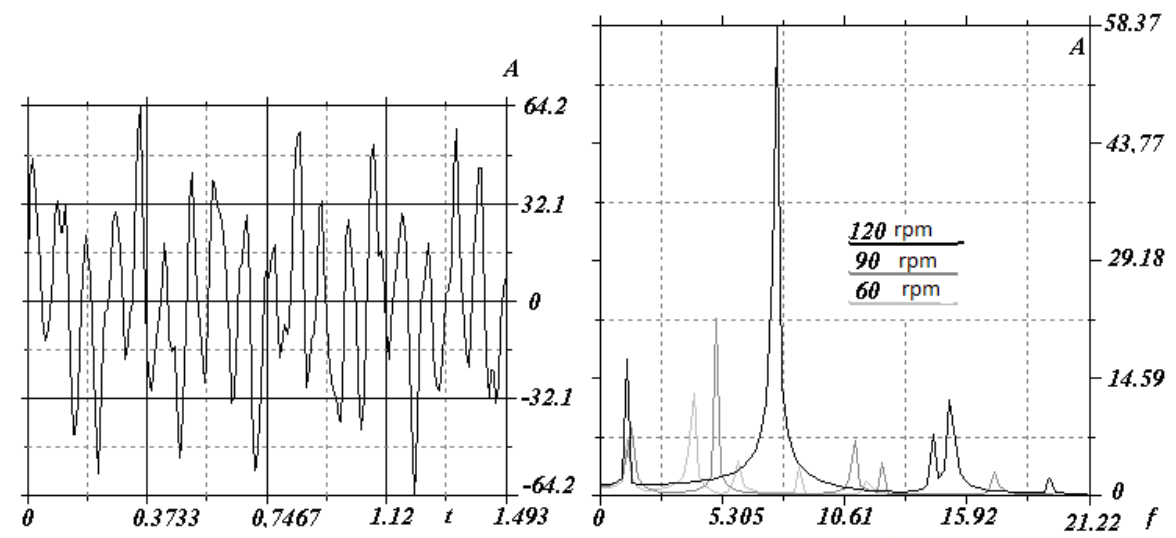

Fig.4. Oscillogram of the pressure cross-arm vibration shift of the drill head at a frequency of $60 \mathrm{rpm}$ $(a, c)$ and spectra of the amplitude-frequency characteristics of oscillations (b, d) of the SBSh$250 \mathrm{MN}-32$ drilling rig with a thyristor drive $(\mathrm{a}, \mathrm{b}-\mathrm{DC}$; $\mathrm{c}, \mathrm{d}-\mathrm{AC})$ when axial pressure $250 \mathrm{kN}$, drilling with three drill rods: A - vibration shift, $\mu \mathrm{m} ; t$-current time, $\mathrm{s} ; f$-frequency of oscillations, $\mathrm{Hz}$.

The operation oscillograms of the transistor drive rotation system (independent power source with pulse-width modulation inverter) of the SBShS-250N drilling machine string are shown in Fig. 3b (drilling on leached oxidized martit-hematite hornblendes: hardness factor according to the M.M. Protodyakonov's scale - 13-15; IV drilling category according to the scale of the Mining and Processing Plant, very fractured, the distance between the fractures is $0.2-0.3 \mathrm{~m}$; axial pressure on drill string $250 \mathrm{kN}$ ), from which it follows that the increase in the pass band of the rotation frequency loop to a value of $200 \mathrm{rad} / \mathrm{s}$ and a decrease in natural oscillation frequencies of the drill string leads to an increase in oscillations amplitude of the motor shaft rotation frequency. The ripples of the motor current are $27.1 \%$, the ripples of the rotation frequency of the motor shaft $-3.02 \%$.

In the amplitude-frequency characteristics when drilling with three rods (Fig.4a, b), peak values appear at frequencies of 1.02 and $2.361 / \mathrm{s}$. When changing the rotation speed of the drill string, these frequencies do not change their values. This pattern can be explained by the influence of the natural oscillation frequencies of the drill string itself on the vibration shift. 
From comparisons of the vibration curves harmonic analysis results it follows that when drilling rocks with similar physical and mechanical properties with the same operating conditions of the vibration amplitude of the drill string in SBShS-250N machines with a transistor AC drive are higher, than in SBSh-250MN-32 machines with thyristor DC drive.

With an increase in the contact hardness of rocks that are drilled, the difference in the vibration indices of machines with drive systems of constant and alternating currents are becoming more evident.

\section{Results and discussion}

The harmonic analysis results of dependences of the drilling rigs vibration parameters on the drive systems are represented in Table 2.

Table 2. Quantitative characteristics of the ripples value depend on the types of rotation electric drives and drilling rigs.

\begin{tabular}{|l|c|c|}
\hline \multirow{2}{*}{$\begin{array}{c}\text { The drive types of drill string rotation } \\
\text { and drilling machines }\end{array}$} & \multicolumn{2}{|c|}{ Range of ripples during drilling, \% } \\
\cline { 2 - 3 } & $\begin{array}{c}\text { electromotor rotation } \\
\text { frequency (drill string) }\end{array}$ & electromotor current \\
\hline $\begin{array}{l}\text { Thyristor DC drive, drilling machine } \\
\text { SBSh -250MN-32 }\end{array}$ & 0.51 & 28.4 \\
\hline $\begin{array}{l}\text { Thyristor AC drive -AM, drilling } \\
\text { machine SBSh -250MN-32 }\end{array}$ & 2.56 & 25.3 \\
\hline $\begin{array}{l}\text { Transistor AC drive ACI - PWM- AM, } \\
\text { drilling machine SBSh -250MN-32 }\end{array}$ & 3.51 & 25.6 \\
\hline $\begin{array}{l}\text { Transistor AC drive AVI-PWM-AM, } \\
\text { drilling machine SBShS -250N }\end{array}$ & 3.02 & 27.1 \\
\hline
\end{tabular}

Analyzing the experimental data obtained in the mining and geological conditions of the Central Mining and Processing Plant, the following generalizations can be made:

- increasing the bit rotation speed leads to an increase in the frequency and amplitude of the drill rod oscillations;

- the axial pressure on drill rod practically does not affect the frequency value of the forced oscillations;

- when increasing the drilling depth, the amplitudes of vibration increase due to a decrease in the rigidity of the transmission (since with an increase in the well depth, the operating frequencies of rotation become less).

A new pattern appeared in the SBShS-250N drilling machine with a transistor AC drive: with an increase in the rotation frequency of the drilling bit, the objectionable amplitudes of the drill rod oscillations appear at frequencies lower than those of the SBSh-250MN-32 machine with a DC drive.

The factors that cause the vibration of the drill assembly during the destruction of a mine rock can be divided into two classes:

- the external disturbances arising from the interaction of the rolling bit with the face surface and the drill rod impact in the drilling process against the inner well surface;

- the internal disturbances arising from the natural oscillations of the drill rods.

The first factors are caused by the shock impacts on both the rolling bit and the drill rod. These effects lead to occurrence of low and high frequency oscillations. The interaction of the drill rods with the surface of the drilled well causes oscillations with a frequency equal to the frequency of the drill string rotation. An increase in the latter leads to a corresponding increase in the disturbance frequency. With a completely regular vertical location of the drill string and a smooth inner surface of the well, these disturbances are 
absent.

The interaction of the three-rolling bit with the face surface leads to the generation of the disturbance effects with a tripled frequency relative to the rotation frequency of the drill string. Due to the pliability of the cable-pulley block system, a wavy surface is formed on the face. In the presence of a completely rigid system of feeding the bit to the face, the face surface would be almost flat and rolling the bit would not cause such kind of disturbance. The immersion of the bit slugs into the mine rock causes high-frequency oscillations with small amplitudes.

The second factor is caused by the dynamic properties of the drill string, and the natural frequencies of oscillations vary depending on the number of screwed rods on the drill string and do not depend on the frequency of the bit rotation. With an increase in the rotation frequency of drill string of the SBSh-250MN-32 machine, regardless of the drive system type, the frequencies of the forced oscillations of the drill string increase proportionally. In the spectra of amplitude-frequency characteristics of vibrations, in addition to the first harmonic, the harmonics are distinguished, which frequency is a multiple of three relative to the frequency of the drill string rotation. This pattern is manifested regardless of the rotation frequency. The latter indicates that, in the drive systems of SBSh -250MN-32 machines, the drill string is exposed to forced oscillations and the natural oscillations do not influence on drill string in the studied frequency range of rotations and pressures.

In the spectra of the amplitude-frequency characteristics of the drill string vibrations of the SBShS-250N drilling machine, a harmonic appears at a frequency of $f=15.92 \mathrm{~Hz}$, independent of the rotation frequency. Other harmonic components follow the same patterns that are typical for the SBSh-250MN-32 drilling machine. The occurrence of the harmonic of the drill string oscillations, which does not depend on its rotation frequency, indicates the manifestation of the internal dynamics of the drill string in the drilling process. Thus, in SBShS-250N drilling machines, when developing the drive systems, it is necessary to take into account the natural frequencies of the drill string.

At a rotation frequency of $120 \mathrm{rpm}$, there is a convergence of the natural and forced oscillations of the drill string, that is, the latter operates in a mode close to mechanical resonance, which negatively affects the durability of the nodes and the drilling machine as a whole.

Now a general industrial electric drives are mounted on drilling machines, at which the performance of energy-efficient drive systems, accepted for operation, is tested. At the next implementation stages, it is necessary to take into account the specifics of the drilling machine operation. The production of object-oriented electric drives requires the analysis and consideration of technological factors that are not taken into account when developing the general industrial electrical equipment for universal use.

\section{Conclusions}

As a result of performed analysis of the state of the blast-holes drilling with the rolling bit method and experimental studies of ways to improve the drive systems of drilling machines introduced according to the recommendations and with the participation of the authors in the open-pit mining in Ukraine, it has been established that:

1. Now one of the main problems of the open-pit method of mining in the quarries of Ukraine is the physical and moral aging of mining equipment, in particular drilling machines. Therefore, the modernization of the existing park and the creation of a new generation of drilling machines is an important scientific and applied problem, on the successful solution of which depends the competitiveness of domestic mining production in the world market. 
2. The creation of domestic rolling bit drilling machines is carried out by teams of special design bureaus of Novokramatorsky Mashinostroitelny Zavod PJSC (Kramatorsk city), Kryvorizhndpirudmash Research and Design Institute for Ore Mining Machine Building, PUBJSC, Kryvorizkyj Zavod Girnychogo Mashynobuduvannya, VAT (Krivyi Rih city), which improve the mechanical and hydraulic equipment of drilling machines, but continue to use traditional thyristor drive systems with DC motors.

3. Along with the improvement of drilling machines hydro-mechanical equipment, it is also necessary to improve the drive systems, which should correspond to the achieved level in the global electrical engineering industry. Only in this case it is possible to create a competitive drilling machine as a whole.

4. In general-industrial drive systems, there is a steady tendency - the introduction of frequency-controlled short-circuited induction motors using autonomous voltage or current inverters.

5. As part of the work carried out by the Dnipro University of Technology in cooperation with LLC ORKIS, in the process of upgrading the electrical equipment of drilling machines, unique AC drive systems for SBSh-250MN-32 drilling were implemented, which have been in operation at the Central Mining and Processing Plant since 1999. The experience has been acquired of industry usage of the transistor AC drive in the conditions of exploitation in open mining operations with the increased level of vibrations, the presence of conductive dust, a sharp temperature difference etc.

6. Changing the type of drive system and the parameters of the drilling machines has led to a change in the operating conditions of the entire electromechanical system:

- the range of ripples of the rotation frequency during the drilling period for $\mathrm{AC}$ drive systems on the SBShS-250N drilling machine of new generation reaches $3.02 \%$, which is more than for the DC drives $(0,51 \%)$ and AC drives $(2.56 \%)$ on SBSh-250MN-32drilling machines;

- the range of ripples of the rotation frequency during the drilling period for AC drive systems of SBSh-250MN-32 drilling machines with the induction motor powered by independent power source with pulse-width modulation inverter reaches $3.51 \%$, which is higher than when the induction motor is connected to an independent current inverter - it does not exceed $2.56 \%$;

- the pass band of the external control loop of the transistor AC drive (it reaches up to $200 \mathrm{rad} / \mathrm{s}$ ) is higher than the pass band of the analogous loops of the DC and AC thyristor drives (not exceed the value of $50 \mathrm{rad} / \mathrm{s}$ );

- the transistor AC drive system when powering the induction motor from independent power source with pulse-width modulation in the SBShS-250N drilling machine of new generation, suppresses the oscillations weaker in the external loop of rotation frequency control (ripples 3.02\%) than the thyristor DC system (ripples $0.51 \%$ ) in the SBSh-250MN32 drilling machines;

- the range of ripples of current and torque moment during the drilling for drives of DC (28.1\%) and AC (25.3\%) of modernized drilling machines (SBSh-250MN-32-25.6\%) and drilling machines of new generation (SBShS-250N-27.1\%) are almost the same.

\section{Direction of further research}

The performed experimental research makes it possible to formulate the following scientific and applied problems:

1. When developing object-oriented $\mathrm{AC}$ drive systems for drilling machines, it is necessary to take into account the natural frequencies of the mechanical transmission oscillations in the dynamics of control, as well as the possibility of suppressing the influence of natural frequencies of the transmission oscillations in the internal control loops 
of the control system, which is facilitated by an increased operation speed of the transistor converter.

2. Currently, the problem of mutual dynamic characteristics influence of the transistor $\mathrm{AC}$ electric drives, as well as the frequency characteristics of the drilling machines transmission is not fully studied and is relevant. This is due to the introduction of both drilling machines with new design solutions and new-generation drives, which has changed the natural frequencies of the electromechanical system oscillations of the drill assembly rotation.

3. To construct a scientific concept of creating the object-oriented drives of drill string rotation for new generation of rolling bit drilling machines, in accordance with the goals and objectives of the study, it is necessary:

- In the area of tasks for analyzing the drill assembly while drilling process as a control object for SBSh-250MN-32 and SBShS-250N drilling machines:

- to develop a mathematical model of a drill assembly as a mechanical system with distributed parameters;

- to analyze the natural frequencies of transversal, torsional and longitudinal oscillations of the drill string with a variable number of connected rods in the well drilling process.

- In the area of tasks for developing a scientific concept of a drive system creation for the drill string rotation:

- to determine the principles of building a regulation system with control of the power flow in the face zone;

- to research the stability of the power flux control system of the drill string rotation drive;

- to analyze the influence of the elastic properties of the drill string on the dynamic processes in the rotation drive.

- In the area of tasks for correcting the drive systems dynamics with complex transmissions when changing the added masses, to which the mechanisms of the drill assembly rotation belong:

- to develop an active sequential correction method using fuzzy control in electric drive control systems in complex electromechanical installations;

- to develop a method for calculating the training sets at the input and output of fuzzy regulators based on the use of cluster analysis algorithms and neural network training.

4. To solve these problems, it is necessary to further develop the theory of electromechanical processes and effective methods for suppressing the elastic oscillations in transmissions in multi-loop control systems. Scientific results, taken together, will make a significant contribution to the solution of an important scientific and applied problem of the dynamic characteristics compatibility of modern high-speed drives with frequency properties of drilling machines of a new generation, which will lead to an increase in the efficiency of mining enterprises of Ukraine with the open method of mining.

The authors consider it their pleasant duty to express gratitude to everyone who contributed to the possibility of implementing this project. This project would have been impossible without the support of the engineering corps and the management of the Novokramatorskyi Mashynobudivnyi Zavod PJSC, the Central Mining and Processing Plant, LLC ORKIS.

\section{References}

1. Kolosov, V., Volovik, V., \& Dyadechkin, N. (2000). Sovremennoe sostoyanie i perspektivy razvitiya predpriyatiy po dobyche i pererabotke zhelezorudnogo i flyusovogo syr'ya v Ukraine. Gornyy Zhurnal, (6), 162-164. 
2. Byzov, V., Paran'ko, I., \& Yevtekhov, V. (2000). Potentsial nedr Ukrainy. Gornyy Zhurnal, (6), 138-140.

3. Storchak, S. (2005). Perspektivy roznichnoy torgovli tovarami ukrainskogo proizvodstva. In Forum Hirnykiv (pp. 99-106). Dnipropetrovsk, Ukraine: Nationalnyi hirnychyi universytet.

4. Kolosov, V., \& Dyadechkin, N. (2005). Sostoyanie i perspektivy razvitiya kristallicheskoy bazy gorno-metallurgicheskogo kompleksa Ukrainy. Gornyy zhurnal, (2), 10-13.

5. Pankov, V. (2005). Sozdanie i proizvodstvo novykh mashin na NKMZ dlya gornodobyvayushchey promyshlennosti. Gornyy zhurnal, (2), 92-94.

6. Kalashnikov, O., \& Dzerzhinskiy, V. (2002). Formirovanie tekhnicheskoy politiki AO "NKMZ" $\mathrm{v}$ oblasti proizvodstva gornogo oborudovaniya. Zbirnyk Naukovykh Prats Natsionalnoi Hirnychoi Akademii Ukrainy, 13(2), 146-152.

7. Khilov, V.S. (2013) Sistemy upravleniya avtomatizirovannymi elektroprivodami kar'yernykh stankov sharoshechnogo bureniya. Dnipropetrovsk: Natsionalnyi hirnychyi universytet.

8. Kikhtenko, V., \& Muchinskiy, Yu. (2001). Burovye stanki srednego tipa. In Perspektyvy Rozvytku Hirnychorudnoi, Vuhilnodobuvnoi $i$ Zbahachuvalnoi Haluzei Promyslovosti (pp 35-36). Kramatorsk: Novo-Kramatorskyi mashynobudivnyi zavod.

9. Strabykin, N., \& Belyaev, A. (2003). Sostoyanie i puti sovershenstvovaniya burovoy tekhniki novogo pokoleniya dlya kar'yerov Sibiri i Severo-Vostoka Rossii. Gornye Mashiny i Avtomatika, (4), 5-9.

10. Beckert, U., \& Neuber, W. (2000). Neues Mebverfahren fur den Schlupf von Asunchron-motoren. Elektrie, (44), 58-60.

11. Bernett, S. (2000). Recent developments of high power converters for industry and tractions applications. IEEE Trans. On Power Elect, 15(6), 1102-1117.

12. Rodriguez, J., J.S. Lai, J., \& Peng, N. (2002). Multilevel inverter: A survey of topologies, controls and applications. IEEE Trans. on Ind. Electron, 49(4), 724-738.

13. Mikitchenko, A.(1999). Razrabotka chastotno-upravlyaemogo elektroprivoda po sisteme NPCHAD dlya mashin predpriyatiy gornodobyvayushchey promyshlennosti. Vestnik Orlovskogo Gosudarstvennogo Universiteta, (3), 108-112.

14. Quang, N., \& Dittrich, J. (2010). Vector Control of Three-Phase AC Machines: System Development in the practice (Power Systems). New York: Springer.

15. Novotny, D., \& Lipo, T. (1996) Vector control and dynamics of AC drives. New York: Oxford science publications.

16. Boldea, I., \& Nasar, S. (2006) Electric drives. New York: CRC Press Taylor \& Francis Group.

17. Khilov, V., Beshta, A., \& Zaika V. (2004). Opyt primeneniya chastotno-upravlyaemykh privodov v burovykh stankakh kar'yerov Ukrainy. Gornyy informatsionno-analiticheskiy byulleten', (10), 285-289.

18. Khilov, V. (2013). A solution to the problem of frequency compatibility between drive system and dynamic parameters of drilling rings. Energy Efficiency Impotent of Geotechnical Systems, 93-103.

19. Khilov, V. (2012). Doslidzhennia dynamiko-informatsiinykh kharakterystyk zovnishnoho konturu pryvoda peresuvannia burovoho postavu. Naukovyi Visnyk Natsionalnoho Hirnychoho Universytetu, (2), 92-97.

20. Khilov, V. (2012). Doslidzhennia informatsiino-analitychnykh vlastyvostei elektromekhanichnoi systemy pry neliniinii korektsii za zavdanniam potuzhnosti. Naukovyi Visnyk Natsionalnoho Hirnychoho Universytetu, (4), 114-120.

21. Kozhevnikov, A., Khilov, V., \& Bel'chitskiy, A., Borisevich, A.(2012). Eksperimental'nye issledovaniya tekhnologii bureniya s impul'snym vrashcheniem instrumenta. Naukovyi Visnyk Natsionalnoho Hirnychoho Universytetu, (6), 86-91.

22. Pivnyak, G., Beshta, A., \& Khilov, V. (2004). Upravlenie privodom vrashcheniya stava sharoshechnogo bureniya na osnove asimptoticheskogo identifikatora sostoyaniya. Elektrotekhnika, (6), 23-26. 
23. Khilov, V., \& Plakhotnik, V. (2004). Otsenka sobstvennykh chastot burovoy shtangi pri nestatsionarnykh rezhimakh. Zbirnyk Naukovykh Prats Natsionalnoho Hirnychoho Universytetu, 19(4), 145-150.

24. Khilov, V. (2004). Identifikatsiya momenta soprotivleniya, chastoty vrashcheniya i moshchnosti na sharoshechnom dolote pri vrashchatel'nom burenii. Visnyk Kryvorizkoho Derzhavnoho Pedahohichnoho Universytetu, 5(28), 16-20.

25. Pivnyak, G., Beshta, A., \& Khilov, V. (2008). Method of Active Successive Correction using Fuzzy Control for Electric Drives of Complex Electromechanical Installations. Technsche Universitat Bergakademie, 59-66.

26. Beshta, O.S. (2012). Electric drives adjustment for improvement of energy efficiency of technological processes. Naukovyi Visnyk Natsionalnoho Hirnychoho Universytetu, (4), 98-107.

27. Pivnyak, G., Beshta, A., \& Balakhontsev, A. (2010). Efficiency of water supply regulation principles. New Techniques and Technologies in Mining - Proceedings of the School of Underground Mining, 1-7. https://doi.org/10.1201/b11329-2

28. Pivnyak, G., Beshta A., \& Khilov V. (2005). AC drive system for actuator's power control. In XIII International Symposium on Theoretical Electrical Engineering ISTET'05 (pp. 368-370). Lviv, Ukraine.

29. Khilov, V. (2013). Sposob upravleniya protsessom bureniya. Patent No. 61548, Ukraina. 